\title{
Molecular detection of virulence genes associated with pathogenicity of Gram positive isolates obtained from respiratory tract of apparently healthy as well as sick goats
}

\author{
Tushar Kisan Aher, Ashish Roy, Pranay Kumar \\ Department of Veterinary Microbiology, \\ College of Veterinary Science and Animal Husbandry, \\ Anand Agricultural University, Anand- 388001. (Gujarat) India. \\ Corresponding author: Tushan Kisan Aher, email:drtusharaher@yahoo.in \\ Received: 30-04-2012, Accepted: 18-05-2012, Published Online: 22-09-2012
}

doi: $10.5455 /$ vetworld.2012.676-681

\begin{abstract}
Aim: To know the prevalence of gram positive isolates and their virulence genes obtained from respiratory tract of apparently healthy as well as sick goats.

Material and Methods: Nasal swabs and tissue samples were screened for the presence of microbial pathogens by cultural isolation, biochemical confirmation. Further, these isolates were subjected to the virulence gene detection by PCR.

Results: Out of 144 isolates, 57 isolates of gram positive pathogens were obtained and confirmed as Staphylococcus spp. (43 isolates) and Streptococcus spp. (14 isolates) on the basis of Gram staining, morphology, cultural identification and biochemical characters. Five isolates (11.6\%) were found to be positive for Coagulase gene; 11 isolates $(25.6 \%)$ were found to be positive for $c l f A$ gene; and 14 isolates (32.6\%) were found to be positive for Spa gene.

Conclusion: The presence of these genes confirmed the pathogenic potential of gram positive pathogens and their association with clinical manifestations in respiratory tract infections of goats.

Key Words: biochemical characters, PCR, respiratory tract of Goat, Staphylococcus, Streptococcus, virulence genes
\end{abstract}

To cite this article: Aher TK, Roy A, Kumar P (2012) Molecular detection of virulence genes associated with pathogenicity of Gram positive isolates obtained from respiratory tract of apparently healthy as well as sick goats, Vet World, 5(11): 676-681, doi: 10.5455/vetworld.2012.676-681

\section{Introduction}

Staphylococci and Streptococci are group of bacteria that cause a wide spectrum of clinical manifestations, such as pneumonia, wound infections, septicemia, endocarditis, mastitis and metritis in animals. It is responsible for both nosocomial and community-acquired infections [1]. These species occur as commensals on skin and mucous membranes; some may act as opportunistic pathogens causing pyogenic infections. They are gram positive cocci (1 $\mu \mathrm{m})$ that tend to occur in irregular clusters resembling bunches of grapes. They are facultative anaerobes, fermentative and catalase positive. They are nonmotile, oxidase-negative and do not form spores. Streptococcus species having similar characteristics as Staphylococcus species but are catalase negative and found in chain of different lengths; acts as commensals on the mucosae of the upper respiratory tract and lower urogenital tract [2]. Many species are saprophytic including those of veterinary importance. These both are major pathogens having wide host range and are associated with various clinical manifestations in small ruminants, viz., pneumonia, mastitis and pyogenic infections.

clfA gene codes for clumping factor, helps in infection process by facilitating bacterial binding via solubilised or immobilized fibrinogen. Because fibrinogen plays significant role in platelet thrombus formation, it is likely that clfA may be involved in bacterial platelet interactions. Therefore, it is implicated as virulence factor [3]. spa gene codes for the IgG binding region of the protein A and is well known for the binding ability for its immunoglobulin $\mathrm{Fc}$ region. spa has affinity with solubilised or immobilized von Willebrand factor (vWF) and identified as a novel Staphylococcal adhesin [4]. coa gene codes for enzyme coagulase and coagulase production is important phenotypic determinant of $S$. aureus which is associated with virulence [5]. In addition to these, it produces several other extracellular virulence factors which affect the host cell metabolism. These genes are associated with the 
Table 1. Primers used for amplification of virulence genes of Staphylococcus spp.

\begin{tabular}{llccc}
\hline Primers & Sequences (5' - 3') & Target gene & Size of amplified product(bp) & Reference \\
\hline coa F & ATA GAG ATG CTG GTA CAG G & coa & polymorphism & 5 \\
coa R & CTT CCG ATT GTT CGA TGC & & 980 & 3 \\
clfA F & GGC TTC AGT GCT TGT AGG & clfA & & \\
clfA R & TTT TCA GGG TCA ATA TAA GC & & 920 & 4 \\
Spa F & CAC CTG CTG CAA ATG CTG CG & spa & & \\
Spa R & GGC TTG TTG TTG TCT TCC TC & & & \\
\hline
\end{tabular}

coa, codes for coagulase; clfA, codes for clumping factor; spa, codes for the IgG binding region of the protein $A$.

Table 2. Primers used for amplification of virulence genes of Streptococcus spp.

\begin{tabular}{llccr}
\hline Primers & Sequences (5'- $\mathbf{3}^{\prime}$ ) & Target gene & Size of amplified product(bp) & Reference \\
\hline bcaF & TAA CAG TTA TGA TAC TTC ACA GAC & bca & 535 & 6 \\
bcaR & ACG ACT TTC TTC CGT CCA CTT AGG & rib & 382 & 6 \\
ribF & CAG GAA GTG CTG TTA CGT TAA AC & rib & & 6 \\
ribR & CGT CCC ATT TAG GGT TCT TCC & & & 6 \\
\hline
\end{tabular}

bca, codes for alpha-C protein; rib, codes for surface Rib protein.

virulence of $S$. aureus.

rib gene codes for surface Rib protein and it has role in putative virulence. $b c a$ gene codes for alpha-C protein and is thought to play a role in epithelial cell adherence and invasion, and resistance to phagocytosis [6]. These genes are associated with the virulence of Streptococcus spp.

In the present study, the animals were screened for the respiratory tract infections caused by Staphylococcus spp. and Streptococcus spp. by cultural and molecular techniques. Along with their primary and secondary biochemical characteristics, the isolates were also examined for the presence of various virulence associated genes by PCR to study their possible role in pathogenicity.

\section{Materials and Methods}

Sample collection: During the present study, a total of 102 nasal swabs were collected from apparently healthy and sick goats from organized farms and 96 tissue samples were collected from post-mortem animals and animals slaughtered in the local meat market and transported to the laboratory on ice. All the samples were processed and screened for possible microbial pathogens.

Cultural isolation of the organisms: Bacterial isolation was done following standard technique by inoculating tissue samples and nasal swabs primarily on blood agar and plates were incubated for 24-48 hrs at $37^{\circ} \mathrm{C}$. After incubation, the nature of growth and cultural characters of colonies were studied. Preliminary morphological identification was done based on Gram's staining. Cultural characteristics of the isolates were further studied on Potassium Tellurite Agar,
Nutrient agar and Mannitol salt agar (HiMedia).

Biochemical identification of Gram positive pathogens: Primarily the isolates were characterized by $\mathrm{KOH}$, Catalase, Oxidase and O-F tests [2]. Following primary biochemical tests, the isolates were characterized by various secondary biochemical tests [7]. Secondary biochemical tests include Coagulase Test, t-DNAse production, Voges-Proskeur (VP) test, CAMPreaction, Lancefield grouping and Carbohydrate fermentation test.

DNA Extraction: The template DNA from colony was prepared with minor modifications [8]. Briefly, from the culture plate, bacterial colonies were picked and suspended in $100 \mu \mathrm{l}$ milli-Q water. The samples were boiled for $15 \mathrm{~min}$, cell debris was removed by centrifugation at $5000 \mathrm{rpm}$ and the supernatant was collected and used as a template DNA.

Polymerase chain reaction (PCR) for amplification of virulence associated genes: PCR was carried out with template DNA ( $3 \mu \mathrm{l})$, forward and reverse primers $(1 \mu \mathrm{l}), 12.5 \mu \mathrm{l}$ of master mix $(2 \mathrm{x})$ and $7.5 \mu \mathrm{l}$ DNAse Free Water in a total volume of $25 \mu$ l. The DNA was amplified using the specific cycling conditions (Table 2). PCR products were separated in $1.5 \%$ agarose gel for $90 \mathrm{~min}$ at $80 \mathrm{~V}$, stained with ethidium bromide (1\%) [added @ $0.5 \mu \mathrm{l} / 100 \mathrm{ml}$ ] and detected by UV transillumination (wavelength 312 nm) [9]. Amplified genes were identified on the basis of fragment size shown in Table 1 and the cyclic conditions for PCR are explained in table 2 .

\section{Results and Discussion}

After morphological, cultural and primary 
Molecular detection of virulence genes associated with pathogenicity of G+ve isolates obtained from goats

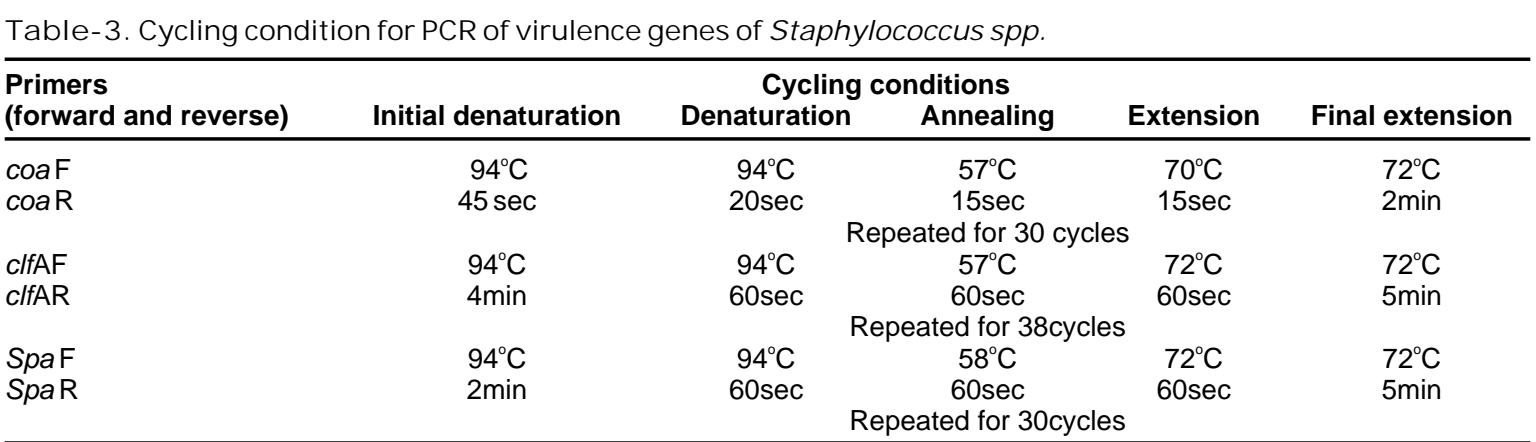

Table 4. Cycling condition for PCR of virulence genes of Streptococcus spp.

\begin{tabular}{|c|c|c|c|c|c|}
\hline $\begin{array}{l}\text { Primers } \\
\text { (forward and reverse) }\end{array}$ & Initial denaturation & $\begin{array}{l}\text { Cycling } \\
\text { Denaturation }\end{array}$ & 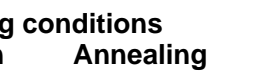 & Extension & Final extension \\
\hline $\begin{array}{l}\text { bca F } \\
\text { bca R }\end{array}$ & $\begin{array}{l}95^{\circ} \mathrm{C} \\
5 \mathrm{~min}\end{array}$ & $\begin{array}{l}94^{\circ} \mathrm{C} \\
30 \mathrm{sec}\end{array}$ & $\begin{array}{c}55^{\circ} \mathrm{C} \\
30 \mathrm{sec} \\
\text { Repeated for } 35 \mathrm{cycles}\end{array}$ & $\begin{array}{l}72^{\circ} \mathrm{C} \\
2 \mathrm{~min}\end{array}$ & $\begin{array}{l}72^{\circ} \mathrm{C} \\
10 \mathrm{~min}\end{array}$ \\
\hline $\begin{array}{l}\text { Rib F } \\
\text { Rib R }\end{array}$ & $\begin{array}{l}95^{\circ} \mathrm{C} \\
5 \mathrm{~min}\end{array}$ & $\begin{array}{l}94^{\circ} \mathrm{C} \\
30 \mathrm{sec}\end{array}$ & $\begin{array}{c}55^{\circ} \mathrm{C} \\
30 \mathrm{sec} \\
\text { Repeated for } 35 \mathrm{cycles}\end{array}$ & $\begin{array}{l}72^{\circ} \mathrm{C} \\
2 \mathrm{~min}\end{array}$ & $\begin{array}{l}72^{\circ} \mathrm{C} \\
10 \mathrm{~min}\end{array}$ \\
\hline
\end{tabular}

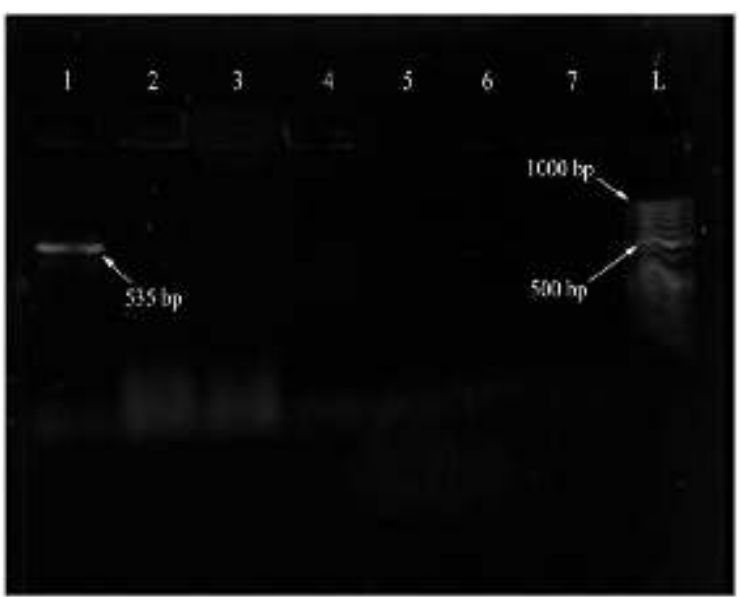

Figure-1. Agarose gel showing amplification product of bca gene for Streptococcus spp. (approximately 535bp) Lane1: Positive field isolates

Lane 2-7: Negative field isolates

L: 100 bp- 1 Kbp DNA ladder

biochemical identification, 43 isolates of Staphylococcus were confirmed. Out of theses 43 isolates, 15 isolates showed yellow discoloration on Mannitol salt agar, 25 isolates showing partial hemolysis on Blood agar, 13 isolates showed golden yellow pigmentation on Nutrient agar and all isolates produced black colonies on Potassium tellurite agar. All Staphylococcus isolates were found to be negative for t-DNAse production and 5 isolates were positive for Coagulase production. In the present study, the prevalence of

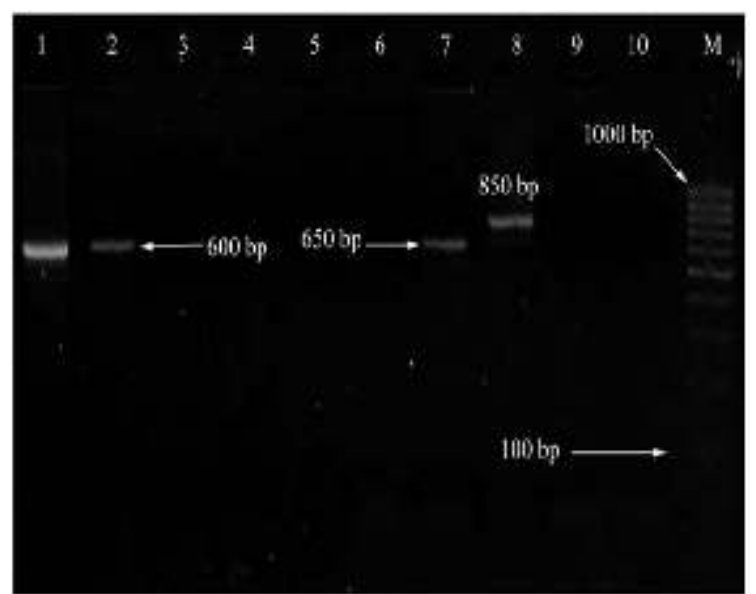

Figure-2. Agarose gel showing amplification product of coa gene for Staphylococcus spp. (approximately $850 \mathrm{bp}, 650 \mathrm{bp}$ and 600bp)

Lane1, 2,7,8: Positive field isolates

Lane 3-6, 9,10: Negative field isolates

L: 100 bp- 1 Kbp DNA ladder

Staphylococcus was found to be $29.9 \%$. The prevalence rate of the present study is in agreement with reports of different authors [10,11]. Higher prevalence of Staphylococcus spp. was detected by one author as $73.7 \%$ from pneumonic lung of goats [12]. Low prevalence of Staphylococcus spp. was detected in the previous study from pneumonic lung of sheep $[13,14,15]$. Lower prevalence of this species was also detected in previous studies which were from pneumonic lung of goats $[16,17]$. Low prevalence of 
Molecular detection of virulence genes associated with pathogenicity of G+ve isolates obtained from goats

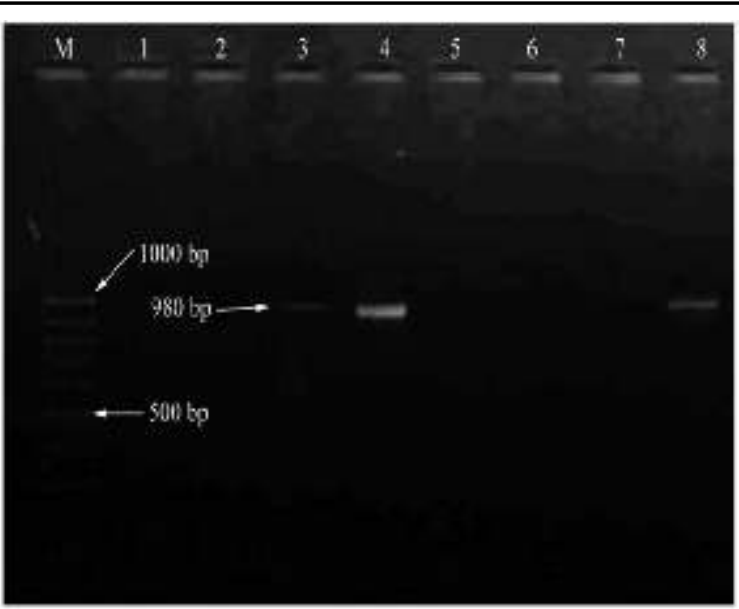

Figure-3. Agarose gel showing amplification product of clfA gene for Streptococcus spp. (approximately 980bp)

Lane 3,4,8: Positive field isolates

Lane 1,2,5, 7: Negative field isolates

M: 100 bp- 1 Kbp DNA ladder

Staphylococcus spp. was also detected from different anatomical sites of respiratory tract of goats [18].

Based on morphological, cultural and preliminary biochemical identification 14 isolates were confirmed as Streptococcus spp. All the isolates were subjected to cultural and secondary biochemical tests for specific identification. Out of 14 isolates, 4 isolates produced partial hemolysis, while others failed to produce hemolysis on sheep blood agar. These isolates were confirmed as Group-D Streptococci, on the basis of Lancefield grouping by using Latex Agglutination Test Kit (HiMedia). All the isolates revealed negative CAMP reaction. These isolates utilized inulin, trehalose, lactose and glucose, except sorbitol. In the present study, the prevalence of Streptococcus spp. was found $9.7 \%$. The reports of the present study are in agreement with reports of previous study $[10,19]$. Low prevalence of Streptococcus spp. were detected in the previous studies $[15,20]$.

The PCR assay was standardized for detection of individual virulence associated genes of Staphylococcus spp. namely clfA gene (codes for clumping factor), spa gene (codes for the IgG binding region of the protein A) and coa gene (codes for enzyme coagulase) using specific primer sequences which gave product sizes of $980 \mathrm{bp}, 920 \mathrm{bp}$ and polymorphism ( $850 \mathrm{bp}, 650 \mathrm{bp}$ and 600 bp), respectively. Five isolates (11.6\%) were found positive for coagulase gene (Fig.2); 11 isolates (25.6\%) were found positive for clfA gene (Fig.3); and 14 isolates $(32.6 \%)$ were found positive for Spa gene (Fig.4). Out of 5 Coagulase positive isolates, 1 isolate revealed an amplified 850 bp product, 2 isolates

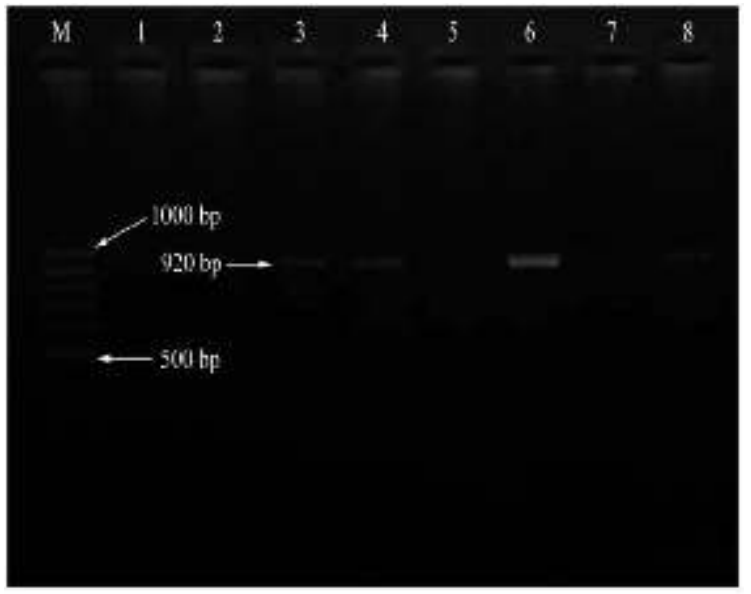

Figure-4. Agarose gel showing amplification product of spa gene for Staphylococcus spp. (approximately $920 \mathrm{bp}$ )

Lane 3,4,6,8: Positive field isolates

Lane 1,2,5,7: Negative field isolates

M: 100 bp- 1 Kbp DNA ladder

revealed an amplified $650 \mathrm{bp}$ product and 2 isolates revealed an amplified 600 bp product. All the coagulase positive isolates of Staphylococcus spp. by in vitro test were also found positive for coagulase gene by PCR detection. The results of the present study were in agreement with reports of previous studies who designed these oligos complementary to each end of the sequence of the clfA and spa genes which specifically amplified the product sizes of 980 bp and $920 \mathrm{bp}$, respectively [3,4]. PCR of coa genes was also carried out in the present study using specific primers resulted in polymorphism $(850 \mathrm{bp}, 650 \mathrm{bp}$ and $600 \mathrm{bp})$. The findings were in contrast with the reports of previous study who used these oligos complementary to each end of the sequence of the coa gene which showed polymorphism and specifically amplified the product sizes of $875,660,603$, or $547 \mathrm{bp}$ [5]. These virulence factors might contribute for mixed respiratory infections in goats. The findings were also in contrast with the previous reports in which 86 positive samples of Staphylococcus spp., were collected, out of that 42 specimens $(48.8 \%)$ contained the coa gene, 63 specimens $(73.3 \%)$ contained the clfA gene and 22 specimens $(25.5 \%)$ contained spa gene (IgG Binding region) [21]. The findings were also in contrast with the previous studies were reported that all the coagulase positive isolates out of collected 92 samples of Staphylococcus aureus, were found to be harbour coa-gene and IgG binding region ( $s p a-\mathrm{IgG})$ whereas, $84(91.3 \%)$ isolates were positive for clfA gene [22]. The reports of present study were in contrast with previous study [23]. 
The PCR assay was standardized for detection of individual virulence associated genes of Streptococcus spp., viz., rib (Codes for surface Rib protein), bca (Codes for alpha-C protein) using primer sequences which yielded a product sizes of $382 \mathrm{bp}$ and $535 \mathrm{bp}$, respectively. Out of total 14 isolates, none of the isolate was confirmed as $S$. agalactiae and none of isolates were found to be positive for $r i b$ gene whereas 2 isolates $(14.3 \%)$ were found to be positive for $b c a$ gene (Fig.1). The results of the present study is in agreement with previous reports who used these oligos complementary to each end of the sequence of the $b c a$ gene which specifically amplified the product size of $535 \mathrm{bp}$, whereas the present results were found in contrast to the previous studies for rib gene using specific primers which amplified the product size of 382 bp [6]. The reports of present study were also found contrast with previous studies $[24,25,26]$. The detection of $b c a$ gene indicated potential antiphagocytic and invasive properties of the isolates.

\section{Conclusions}

Therefore, although the prevalence rate of the organisms in respiratory tract infections is low, the presence of the virulence associated genes provides them considerable pathogenic potential in the cases where the host is immuno-compromised. In view of all the findings, we need to further investigate the role of other factors related to host and pathogen which assist in the progression of disease at physiological and molecular levels.

\section{Author's Contribution}

The work was carried out by TKA under the guidance of AR with the technical support of PK. PK revised the manuscript. All authors read and approved the final manuscript.

\section{Acknow ledgements}

The authors are thankful to the Dean, College of Veterinary Science and Animal Husbandry, Anand, Gujarat for providing the facilities to pursue this work.

\section{Competing interests}

Authors declare that they have no competing interests.

\section{References}

1. Crăciunaş, C., Butiuc-Keul, A., Flonta, M., Almaş, A., Brad, A., Sigarteu, M. (2010). Development of a PCR assay for identification of antibiotic resistance determinants at Staphylococcus aureus, Analele Universită ii din Oradea 2: 248-252.

2. Quinn, P. J., Carter, M. E., Markey, B. K., Cartey, G.
E. (1994) Clinical Veterinary Microbiology. Section 2. Bacteriology, Mosby-Year Book Europe Limited, Lynton House, London, England.

3. Stephan, R., Annemuller, C., Hasan, A. A. and Lammler, C. H. (2001). Characterization of enterotoxigenic $S$. aureus strains isolated from bovine mastitis in northeast Switzerland. Vet. Microbio. 78: 373-382.

4. Seki, K., Sakurada, J., Seong, H. K., Murai, M., Tachi, H., Ishii, H. and Masuda, S. (1998). Occurrence of coagulase serotype among $S$. aureus strains isolated from healthy individuals with special reference to correlation with size of protein-A gene. Microbiol. Immunol. 42: 407-409.

5. Hookey, J. V., Richardson, J. F., and B. D. Cookson. (1998). Molecular typing of Staphylococcus aureus based on PCR restriction fragment length polymorphism and DNA sequence analysis of the coagulase gene. J. Clin. Microbiol. 36:1083-1089.

6. Smith, T. C., Roehl, S. A., Pillai, P., Li, S., Marrs, C. F. and Foxman, B. (2007). Distribution of novel and previously investigated virulence genes in colonizing and invasive isolates of $S$. agalactiae. Epidemiol. Infect. 135: 1046-1054.

7. Barrow, G. I. and Feltham, R. K. A. (1993). Cowan and Steel's Manual for the Identification of Medical Bacteria. $3^{\text {rd }}$ edn. 140-143, Cambridge University Press, Cambridge.

8. Smyth, R.W., Kahlmeter, G., Liljequist, O. B. and Hoffman, B. (2001). Methods for identifying methicillin resistance in Staphylococcus aureus. J. Hosp. Infect. 48: 103-107.

9. Relman, D. A. and Persing, D. H. (1996). Genotypic methods for microbial identification, PCR protocols for emerging infectious diseases: A supplement to Diagnostic Molecular Microbiology: Principles and Applications. ASM Press, Washington, D.C. 3-31.

10. Ramchandran, S. and Sharma, G. L. (1969). Observations on the incidence and histopathology of pneumonia of sheep and goats in India. Ind. Vet. J. 46: 16-29.

11. Asseged, B., Megra, T. and Sisay, T. (2006). The aerobic bacterial flora of the respiratory passageways of healthy goats in Dire-Dawa abattoir, Eastern Ethiopia. Rev. Med. Vet. 157 (2): 84-87.

12. Obi, T. U., Ojo, M. O., Durojaiye, O. A., Kasali, O. B., Akpavie, S. O. and Opasina, B. A. (1983). PPR in goat in Nigeria: Clinical, microbiological and pathological features. Zenbrfalblatt fur veterinarmedizin. 30: 751-761.

13. Garedew, L., Ayelet, G., Yilma, R., Zeleke, A. and Gelaye, E. (2010). Isolation of diverse bacterial species associated with Maedi-visna infection of sheep in Ethiopia. Afr. Jour. Microbio. Res. 4(1): 1421.

14. Richard, Y. J., Menour, N. J., Coiguen, F. J., Avier, C. J., Borges, E., Fontain, M. J., Audar, J., Brunet, J. and Pailhae, C. (1986). Bacteriological study on sheep lungs from the abattoir. Revue Med. Vet. 37: 671-680. 
15. Srinivasan, P., Jyue, M. and Kumar, R. A. (2003). Bacteriological Studies of ovine pneumonia in an organized farm. Ind. Vet. J. 80 (4): 311-313.

16. Sharma, R. K., Boro, B. R. and Borachi, P. C. (1991). Incidence of Caprine Pneumonia and associated bacterial isolates. Ind. J. Anim. Sci. 61:54-55.

17. Al-Qudah, K. M., Al-Majali, A. M. and Obaidat, M. M. (2008). A study on pathological and microbiological conditions in goats in slaughterhouses in Jordan. AJAVA. 3: 269-274.

18. Yimer, N. and Asseged, B. (2007). Aerobic bacterial flora of the respiratory tract of healthy sheep slaughtered in Dessie municipal abattoir, northeastern Ethiopia. Revue Méd. Vét. 158 (10): 473-478.

19. Raji, M. A., Adogwa, A. T., Natala, A. J. And Oladele, S. B. (2000). The prevalence and gross pathologic lesions of ovine and caprine pneumonia caused by bacterial agents in Zaria, Nigeria. Ghana J. Sci. 4: 3-8.

20. Obasi, O. L., Raji, M. A., Adogwa, T. and Natala, A. J. (2001). The effects of climatic factors on occurrence and gross pathological lesions in bacterial pneumonia of ovine and caprine host in Zaria, Nigeria. Glob. J. Pure Appl. Sci. 7 (1): 57-60.

21. Momtaz, H., Rahimi, E. and Tajbakhsh, E. (2010). Detection of some virulence factors in Staphylococcus aureus isolated from clinical and subclinical bovine mastitis in Iran. African Journal of Biotechnology.
9(25): 3753-3758.

22. Karahan, M., Acik, M. N. and Cetinkaya, B. (2011). Investigation of Virulence Genes by PCR in Stapylococcus aureus Isolates Originated from Subclinical Bovine Mastitis in Turkey. Pak. Vet. J. 31(x): xxx.

23. Salasia, S. I. O., Khusnan, Z., Lammler, C., Nirwati, H. (2003). Phenotyping and genotyping of Staphylococcus aureus isolated from human skin infections in Yogyakarta. Indo. J. Biotech. 612-620.

24. Brzychczy-Włoch, M., Gosiewski, T.,Bodaszewska, M., Pabian, W., Bulanda, M., Kochan, P., Strus, M. and Heczko, P. B. (2010). Genetic characterization and diversity of Streptococcus agalactiae isolates with macrolide resistance. $J$ Med Microbiol vol. 59(7): 780-786.

25. Corrêa, A. B. A., Oliveira, I. C. M., Pinto, T. C. A., Mattos, M. C., Benchetrit, L. C. (2009). Pulsedfield gel electrophoresis, virulence determinants and antimicrobial susceptibility profiles of type Ia group B streptococci isolated from humans in Brazil. Mem. Inst. Oswaldo. Cruz. 104: 4.

26. Sadowy, E., Matynia, B. and Hryniewicz, W. (2010). Population structure, virulence factors and resistance determinants of invasive, non-invasive and colonizing Streptococcus agalactiae in Poland. J. Antimicrob. Chemother. 65 (9): 1907-1914. 